\title{
Analisis Biaya Satuan (Unit Cost) dengan Metode Activity Based Costing (ABC) di Poliklinik Jantung RSU dr. H. Koesnadi Bondowoso
}

\author{
Unit Cost Analysis with Method of Activity Based Costing (ABC) \\ in the Heart Polyclinic General Hospital of dr. H. Koesnadi Bondowoso
}

\author{
Sumiati $^{1}$, Eri Witcahyo ${ }^{2}$, Andrei Ramani $^{2}$ \\ ${ }^{1}$ Bagian Administrasi dan Kebijakan Kesehatan, Fakultas Kesehatan Masyarakat, Universitas Jember \\ ${ }^{2}$ Universitas Jember \\ Korespondensi: Eri Witcahyo, \\ e-mail: ewitcahyo@unej.ac.id
}

\begin{abstract}
Abstrak
Penetapan tarif dihitung berdasarkan biaya satuan, berdasarkan Peraturan Bupati Bondowoso Nomor 62 Tahun 2017, RSU dr. H. Koesnadi Bondowoso menghitung biaya satuan dengan metode Double Distribution (DD). Metode Double Distribution (DD) tidak tepat untuk diterapkan karena tidak mencerminkan aktivitas, metode yang berdasarkan aktivitas, tepat dan akurat sehingga dapat memberikan informasi yang tepat adalah metode Activity Based Costing (ABC). RSU dr. H. Koesnadi Bondowoso belum melakukan perhitungan unit cost dengan metode Activity Based Costing $(A B C)$ terutama untuk instalasi rawat jalan. Tujuan dari penelitian ini adalah untuk menganalisis biaya satuan dengan metode Activity Based Costing di poliklinik jantung RSU dr. $\mathrm{H}$. Koesnadi Bondowoso. Metode penelitian dilakukan berdasarkan metode perhitungan Activity Based Costing ( $A B C)$. Unit analisis dalam penelitian ini adalah poliklinik jantung RSU dr. $\mathrm{H}$. Koesnadi Bondowoso. Berdasarkan hasil perhitungan dengan data tahun 2017 maka diperoleh biaya satuan electrocardiogram yaitu Rp. 47.689, echocardiography Rp. 113.212 dan treadmill adalah Rp. 221.547. Kesimpulan menunjukkan bahwa unit cost lebih rendah dari tarif yang ditetapkan.

Kata Kunci: Biaya Satuan, Activity Based Costing (ABC)
\end{abstract}

\begin{abstract}
Determination of rate calculated based on unit cost, based on Bondowoso Regent Regulation Number 62 of 2017, RSU dr. H. Koesnadi Bondowoso unit cost calculates using the Double Distribution method. Double Distribution (DD) method is not appropriate to be applied because it does not reflect activity, method based on activity, precise and accurate so that it can provide the right information is Activity Based Costing (ABC) method. RSU Dr. H. Koesnadi Bondowoso has not made unit cost calculation using Activity Based Costing (ABC) method, especially for outpatient installation. The purpose of this research is unit cost analysis with Activity Based Costing method in the heart polyclinic of RSU Dr. H. Koesnadi Bondowoso. The research method based on Activity Based Costing (ABC) calculation method. The unit of analysis was heart poyclinic at RSU Dr. H. Koesnadi Bondowoso. Unit cost calculated with Activity Based Costing (ABC) method. Based on the calculation result with 2017 data a unit cost obtained, electrocardiogram is Rp. 47,689, echocardiography Rp. 113,212 and treadmill is Rp. 221,547. The conclusion shown that the unit cost is lower than the specified rate. Keywords: Unit Cost, Activity Based Costing (ABC)
\end{abstract}

\section{Pendahuluan}

Rumah sakit merupakan salah satu fasilitas kesehatan yang menyelenggarakan upaya kesehatan. Rumah sakit mempunyai kewajiban untuk memberi pelayanan kesehatan yang aman, bermutu, dan efektif dengan mengutamakan kepentingan pasien sesuai dengan standar pelayanan rumah sakit (Republik Indonesia, 2009). Rumah sakit 
yang BLU atau BLUD dapat menerima biaya dari masyarakat sebagai imbalan barang atau jasa yang telah diberikan. Imbalan tersebut dalam bentuk tarif yang ditetapkan atas dasar perhitungan biaya satuan (Republik Indonesia, 2005).

Perhitungan unit cost memiliki peran penting, diantaranya digunakan untuk penetapan tarif, informasi tentang unit cost digunakan untuk perencanaan anggaran, pengendalian biaya, subsidi, dan sebagai informasi dalam membuat keputusan (Agastya, 2009). Perhitungan unit cost memiliki tujuan supaya efisiensi dan kinerja setiap instalasi, poliklinik maupun komponen dalam proses pelayanan di instansi yang menyelenggarakan pelayanan kesehatan dapat dimonitor dengan baik sehingga perhitungan unit cost bermanfaat untuk memperkuat pertahanan rumah sakit dalam persaingan bisnis yang ketat (Proqua Consulting, 2016).

RSU dr. H. Koesnadi Bondowoso merupakan rumah sakit milik pemerintah yang ditetapkan sebagai rumah sakit kelas B Non Pendidikan. Berdasarkan Keputusan Bupati Bondowoso Nomor 188.45/450/430. 6.2/2011 menetapkan RSU dr. H. Koesnadi Bondowoso sebagai BLUD Penuh. Berdasarkan Peraturan Bupati Bondowoso Nomor 62 Tahun 2017 tentang Tarif Pelayanan Kelas III dan Pelayanan Tanpa Kelas pada RSU dr. H. Koesnadi Kabupaten Bondowoso, RSU dituntut untuk menetapkan tarif layanan kesehatan melalui perhitungan unit cost dengan metode Double Distribution (DD). Perhitungan unit cost dengan metode Double Distribution (DD) tidak tepat untuk diterapkan karena tidak mencerminkan aktivitas yang spesifik dan lebih berdasarkan kepada perkiraan (Hilfi, et al, 2015). Perhitungan unit cost memerlukan metode yang tepat dan akurat sehingga dapat memberikan informasi yang tepat untuk pengambilan keputusan, metode perhitungan yang berdasarkan aktivitas adalah metode Activity Based Costing (ABC) (Hilfi, et al, 2015). Metode Activity Based Costing ( $A B C$ ) memiliki karakteristik khusus yaitu kemampuan untuk mendiagnosis biaya yang tepat, menyajikan informasi non keuangan untuk meningkatkan kinerja dan efisiensi kegiatan. Selain itu, metode ini dapat mengidentifikasi penggunaan sumber daya yang tidak efisien sehingga sumber daya tersebut dapat dikurangi (Rajabi dan Dabiri, 2012).

Berdasarkan studi pendahuluan, RSU dr. H. Koesnadi Bondowoso belum melakukan perhitungan unit cost dengan metode Activity Based Costing $(A B C)$ terutama di instalasi rawat jalan. Metode Activity Based Costing $(A B C)$ sangat penting untuk diterapkan karena memenuhi kebutuhan informasi yang akurat tentang biaya yang dikonsumsi oleh sumber daya, produk pelayanan dan pelanggan (Soekardan, 2016). RSU dr. H. Koesnadi Bondowoso memiliki 16 poliklinik di instalasi rawat jalan dan kunjungan pasien dari tahun ke tahun mengalami peningkatan. Poliklinik jantung memiliki kunjungan yang tertinggi pada tahun 2017, yaitu 11.874 pasien. Poliklinik jantung memiliki 3 produk pelayanan, diantaranya electrocardiogram, echocardio- graphy dan treadmill.

Berdasarkan data yang diperoleh dan dibandingkan dengan poliklinik lainnya, penerimaan poliklinik jantung pada tahun 2017 jauh dibawah sumber daya atau modal yang dikeluarkan. Beberapa pihak juga memiliki keluhan bahwa tarif yang telah ditetapkan tidak rasional. Berdasarkan permasalahan tersebut RSU dr. H. Koesnadi Bondowoso perlu melakukan perhitungan unit cost dengan metode Activity Based Costing $(A B C)$ yang dapat menghasilkan informasi biaya yang akurat di poliklinik jantung RSU dr. H. Koesnadi Bondowoso. Tujuan dari penelitian ini adalah untuk menganalisis biaya satuan dengan metode Activity Based Costing di poliklinik jantung RSU dr. H. Koesnadi Bondowoso.

\section{Metode Penelitian}

Metode penelitian dilakukan berdasarkan metode Activity Based Costing ( $A B C$ ) yaitu identifikasi nama dan biaya aktivitas penunjang, pembebanan biaya ke unit produksi, identifikasi produk pelayanan, 
identifikasi aktivitas produk dan waktu pelayanan, mengitung biaya langsung dan biaya tidak langsung. Pembebanan biaya aktivitas sekunder ke aktivitas primer, dan menghitung biaya satuan (Javid, et al, 2016 dan Rahmaniar dan Rochmah, 2017). Unit analisis penelitian ini adalah poliklinik jantung RSU dr. H. Koesnadi Bondowoso dan penelitian dilakukan mulai pada bulan Juli-Desember 2018. Data perhitungan yang digunakan adalah data biaya bulan JanuariDesember Tahun 2017. Teknik Pengumpulan data dilakukan dengan cara studi dokumentasi, observasi dan wawancara dengan

\section{Hasil}

\section{Aktivitas Penunjang (Facility Activity)}

Berdasarkan hasil wawancara dan menelaah Peraturan Bupati Bondowoso Nomor 12 Tahun 2013 tentang Penjabaran Tugas Pokok dan Fungsi RSU dr. H. Koesnadi diperoleh bahwa aktivitas penunjang (facility activity) poliklinik jantung RSU dr. H. Koesnadi Bondowoso terdiri dari pelayanan manajemen dan administrasi, pelayanan front menggunakan instrumen pengambilan data yaitu lembar check list dan pedoman wawancara. Analisis data dilakukan setelah data-data yang dibutuhkan telah terkumpul. Analisis data penelitian ini menggunakan spreadsheet pada microsoft excel. Menggunakan microsoft excel peneliti membuat tabel untuk input data sesuai dengan kebutuhan setiap tahapan dalam metode Activity Based Costing (ABC), data diolah dengan memasukan rumus yang sesuai dengan perhitungan setiap tahapan dalam metode Activity Based Costing (ABC).

office, pelayanan pengendali, pelayanan rekam medik, pelayanan sistem informasi manajemen rumah sakit (SIM RS), pelayanan kasir, pelayanan farmasi, pelayanan laundry, pelayanan pemeliharaan sarana, pemeliharaan cleaning service, dan pelayanan keamanan. Setiap aktivitas penunjang (facility activity) memiliki jenis cost driver masing-masing. Berikut ini adalah tabel aktivitas penunjang (facility activity) poliklinik jantung dan cost driver.

Tabel 1 Aktivitas Penunjang (Facility Activity) dan jumlah Cost Driver Seluruh RS dan Poliklinik Jantung RSU dr. H. Koesnadi Bondowoso

\begin{tabular}{|c|c|c|c|}
\hline Facility Activity & Cost Driver & $\begin{array}{l}\text { Jumlah CD } \\
\text { Seluruh RS }\end{array}$ & $\begin{array}{c}\text { Jumlah CD Poli } \\
\text { Jantung }\end{array}$ \\
\hline $\begin{array}{l}\text { Pelayanan Manajemen dan } \\
\text { Administrasi }\end{array}$ & $\begin{array}{l}\text { Jumlah Pasien (Kunjungan dan } \\
\text { Tindakan) }\end{array}$ & 940.331 & 11.910 \\
\hline \multirow{2}{*}{$\begin{array}{l}\text { Pelayanan Front Office } \\
\text { Pelayanan Pengendali }\end{array}$} & Jumlah Pasien (Kunjungan) & 84.298 & 11.707 \\
\hline & $\begin{array}{l}\text { Jumlah Pasien (Kunjungan } \\
\text { Asuransi) }\end{array}$ & 70.865 & 11.148 \\
\hline Pelayanan Rekam Medik & Jumlah Pasien (Kunjungan) & 84.298 & 11.707 \\
\hline Pelayanan SIM RS & $\begin{array}{l}\text { Jumlah Pasien (Kunjungan dan } \\
\text { Tindakan) }\end{array}$ & 940.331 & 11.910 \\
\hline Pelayanan Kasir & Jumlah Pasien (Kunjungan Umum) & 13.433 & 559 \\
\hline Pelayanan Farmasi & $\begin{array}{l}\text { Jumlah Pasien (Kunjungan dan } \\
\text { Tindakan) }\end{array}$ & 940.331 & 11.707 \\
\hline Pelayanan Laundry & Jumlah Kg & 39.615 & 64 \\
\hline Pelayanan Pemeliharaan Sarana & Frekuensi Pemeliharaan & 1.732 & 15 \\
\hline Pelayanan Cleaning Service & Luas lantai & 21.071 & 78 \\
\hline Pelayanan Keamanan & Luas Lahan & 46.500 & 100 \\
\hline
\end{tabular}

Berdasarkan tabel 1 dapat diketahui bahwa terdapat 11 aktivitas penunjang (facility activity) yang menunjang poliklinik jantung dan memiliki jenis dan jumlah cost driver masingmasing. 
Biaya Tidak Langsung Aktivitas Penunjang (Facility Activity)

Komponen biaya tidak langsung terdiri dari biaya depresiasi, biaya operasional dan biaya pemeliharaan. Biaya depresiasi meliputi biaya depresiasi gedung, biaya depresiasi alat non medis, dan biaya depresiasi kendaraan. Sedangkan biaya operasional meliputi gaji

Tabel 2 Biaya Tidak Langsung Aktivitas Penunjang (Facility Activity) dan Pembebanan Biaya ke Poli Jantung

\begin{tabular}{|c|c|c|}
\hline Facility Activity & $\begin{array}{c}\text { Jumlah Biaya } \\
(\text { Rp })\end{array}$ & Poli Jantung (Rp) \\
\hline Pelayanan & & \\
\hline $\begin{array}{l}\text { Manajemen dan } \\
\text { Administrasi }\end{array}$ & 3.527 .531 .568 & 44.678 .843 \\
\hline $\begin{array}{l}\text { Pelayanan Front } \\
\text { Office }\end{array}$ & 680.538 .883 & 94.510 .768 \\
\hline $\begin{array}{l}\text { Pelayanan } \\
\text { Pengendali }\end{array}$ & 230.185 .850 & 36.211 .273 \\
\hline $\begin{array}{l}\text { Pelayanan Rekam } \\
\text { Medik }\end{array}$ & 386.539 .186 & 53.681 .158 \\
\hline Pelayanan SIM RS & 92.493 .484 & 1.171 .500 \\
\hline Pelayanan Kasir & 44.124 .193 & 1.836 .181 \\
\hline Pelayanan Farmasi & 906.702 .027 & 11.288 .324 \\
\hline Pelayanan Laundry & 262.980 .710 & 424.858 \\
\hline $\begin{array}{l}\text { Pelayanan } \\
\text { Pemeliharaan Sarana }\end{array}$ & 452.511 .336 & 3.918 .978 \\
\hline $\begin{array}{l}\text { Pelayanan Cleaning } \\
\text { Service }\end{array}$ & 1.258.407.350 & 4.658 .335 \\
\hline $\begin{array}{l}\text { Pelayanan } \\
\text { Keamanan }\end{array}$ & 1.226.381.610 & 2.637 .380 \\
\hline
\end{tabular}

Berdasarkan tabel 2 dapat diketahui bahwa biaya tidak langsung pada aktivitas penunjang (facility activity) yang terbesar adalah pelayanan manajemen dan administrasi dengan jumlah sebesar Rp. 3.527.531.568 dan biaya tidak langsung terkecil adalah pelayanan kasir yaitu sebesar Rp. 44.124.193.

\section{Pembebanan Biaya Tidak Langsung Aktivitas Penunjang (Facility Activity)}

Pembebanan biaya tidak langsung aktivitas penunjang (facility activity) adalah pembebanan biaya pada aktivitas penunjang (facility activity) ke poliklinik jantung berdasarkan rate per cost driver. Rate per cost driver diperoleh dari hasil bagi biaya tidak langsung dengan cost driver seluruh RS. Berdasarkan tabel 2 dapat diketahui bahwa pembebanan biaya terbesar adalah pelayanan front office yaitu sebesar $\mathrm{Rp}$. 94.510.768 dan pelayanan laundry menjadi pelayanan dengan biaya terkecil dengan jumlah Rp. 424.858. karyawan non medis, biaya bahan habis pakai non medis, biaya umum seperti air, listrik, telepon, dan internet, serta biaya lain-lain. Berikut tabel total biaya tidak langsung pada masing-masing-masing aktivitas penunjang (facility activity) yang kemudian di bebankan ke poli jantung.

\section{Aktivitas, Produk Pelayanan dan Waktu Pelayanan Primer}

Aktivitas yang diidentifikasi adalah aktivitas pada produk pelayanan di poliklinik jantung, yaitu terdiri dari electrocardiogram, echocardiography dan treadmill yang memiliki jumlah pelayanan tahun 2017 berturut-turut 9765,1050 dan 1095 . Aktivitas yang telah diidentifikasi kemudian diklasifikasi dan dikategorikan. Klasifikasi aktivitas dalam penelitian ini terdiri atas aktivitas primer dan aktivitas sekunder, sedangkan kategori aktivitas terdiri dari aktivitas unit (unit activity) karena berasal dari pusat aktivitas atau unit produksi. Berdasarkan hasil identifikasi aktivitas setiap produk pelayanan memiliki beberapa aktivitas sekunder dan aktivitas primer dengan jumlah waktu pelayanan primer yang berbeda-beda. Berikut tabel produk pelayanan dan waktu pelayanan primer masing-masing.

Tabel 3 Produk Pelayanan dan Waktu Pelayanan Primer

\begin{tabular}{lc}
\hline \multicolumn{1}{c}{ Produk Pelayanan } & $\begin{array}{c}\text { Total Waktu } \\
\text { Pelayanan Primer } \\
\text { (menit) }\end{array}$ \\
\hline Electrocardiogram & 15 \\
Echocardiography & 29 \\
Treadmill & 42 \\
\hline
\end{tabular}

Berdasarkan tabel 3 dapat diketahui bahwa produk pelayanan yang memiliki total waktu pelayanan primer terbanyak yaitu 42 menit adalah treadmill, electrocardiogram merupakan produk pelayanan yang memiliki total waktu primer terkecil yaitu 15 menit.

\section{Biaya Langsung dan Biaya Tidak Langsung}

Komponen biaya langsung terdiri dari biaya bahan habis pakai medis, biaya tenaga medis dan biaya alat medis. Komponen Biaya tidak 
langsung terdiri dari biaya depresiasi gedung, biaya depresiasi alat non medis, biaya operasional yang terdiri dari biaya gaji tenaga non medis, biaya BHP non medis, biaya umum, biaya perjalanan dinas, dan biaya lain. Total biaya tidak langsung merupakan hasil penjumlahan seluruh komponen biaya tidak langsung untuk poliklinik jantung. Berikut tabel total biaya langsung untuk setiap produk pelayanan dan total biaya tidak langsung poli jantung.

Tabel 4 Total Biaya Langsung Produk Pelayanan dan Biaya Tidak Langsung Poliklinik Jantung Tahun 2017

\begin{tabular}{lcc}
\hline Produk Pelayanan & $\begin{array}{c}\text { Total Biaya } \\
\text { Langsung } \\
(\mathbf{R p})\end{array}$ & $\begin{array}{c}\text { Total Biaya Tidak } \\
\text { Langsung (Rp) }\end{array}$ \\
\hline Electrocardiogram & 25.995 & $18.746 .749+$ \\
Echocardiography & 72.276 & $43.762 .899+$ \\
Treadmill & 161.702 & $2.827 .700=$ \\
& & 65.337 .348 \\
\hline
\end{tabular}

Berdasarkan hasil perhitungan diperoleh total biaya langsung terbesar adalah biaya produk pelayanan treadmill yaitu sebesar Rp. 161.702, sedangkan biaya langsung terkecil dengan jumlah Rp. 25.995 adalah produk pelayanan electrocardiogram. Berdasarkan pada tabel 4 biaya tidak langsung poliklinik jantung adalah sebesar Rp. 65.337.348.

\section{Pembebanan Aktivitas Sekunder ke Aktivitas Primer}

Pembebanan aktivitas sekunder ke aktivitas primer merupakan langkah yang mempunyai fungsi untuk mengalokasikan jenis aktivitas sekunder ke aktivitas primer. Berdasarkan penggabungan aktivitas, klasifikasi dan kategori aktivitas dapat menghitung jumlah pasien yang diidentifikasi dengan menjumlahkan jumlah pelayanan selama tahun 2017 berdasarkan unit activity yang telah dikategorikan. Kemudian jumlah pasien dikalikan dengan waktu pelaksanaan aktivitas untuk memperoleh jumlah cost driver. Biaya tidak langsung pada aktivitas sekunder 1 sampai 11 berasal dari hasil pembebanan aktivitas penunjang (facility activity) ke poliklinik jantung. Biaya Akivitas sekunder 12 sampai 16 yang merupakan aktivitas sekunder dari unit activity, diperoleh dengan cara membagi jumlah cost driver aktivitas sekunder dengan total cost driver kemudian dikalikan dengan biaya tidak langsung poliklinik jantung.

Tahap selanjutnya adalah penentuan alokasi aktivitas sekunder ke aktivitas primer. Penentuannya dilakukan dengan mengelompokkan aktivitas primer yang menggunakan aktivitas sekunder. Kemudian melakukan perhitungan pembebanan biaya tidak langsung aktivitas sekunder ke aktivitas primer. Perhitungan pembebanan tersebut dilakukan dengan cara jumlah cost driver aktivitas primer dibagi dengan jumlah cost driver berdasarkan hasil penentuan alokasi aktivitas sekunder ke aktivitas primer, kemudian dikalikan dengan biaya tidak langsung aktivitas sekunder. Berdasarkan hasil perhitungan pembebanan biaya tidak langsung aktivitas sekunder terbesar adalah aktivitas sekunder 2 ke aktivitas primer 1 sampai 11 yaitu dengan jumlah Rp. 94.510.768, sedangkan yang terkecil dengan jumlah Rp. 424.858 terletak pada aktivitas sekunder 8 ke aktivitas primer 1 sampai 11.

\section{Biaya Tidak Langsung pada Aktivitas Primer Poliklinik Jantung}

Perhitungan biaya tidak langsung pada aktivitas primer dapat diperoleh dengan cara menjumlahkan semua biaya yang telah dibebankan ke aktivitas primer, sehingga akan diperoleh biaya tidak langsung per aktivitas primer. biaya tidak langsung per aktivitas primer terbesar adalah aktivitas primer 2. Biaya tidak langsung per aktivitas primer yang telah didapatkan kemudian dibagi dengan jumlah pasien sehingga memperoleh nilai rate per aktivitas primer. Berdasarkan tabel 5 dapat diketahui bahwa rate per aktivitas primer terbesar adalah aktivitas primer 9 yang dimiliki oleh produk pelayanan treadmill yaitu sebesar Rp. 35.571, sedangkan rate per aktivitas primer terkecil adalah aktivitas primer 4 yang dimilki oleh oleh produk pelayanan electrocardiogram dan echocardiography yaitu sebesar Rp. 1.451. berikut ini tabel 
perhitungan biaya tidak langsung pada aktivitas primer.

Tabel 5 Biaya Tidak Langsung pada Aktivitas Primer Poliklinik Jantung

\begin{tabular}{lrr}
\hline $\begin{array}{c}\text { Aktivitas } \\
\text { Primer }\end{array}$ & $\begin{array}{c}\text { Total BTL Per } \\
\text { Aktivitas Primer } \\
\text { (Rp) }\end{array}$ & $\begin{array}{c}\text { Rate Per } \\
\text { Aktivitas } \\
\text { Primer (Rp) }\end{array}$ \\
\hline P1 & 34.918 .267 & 2.932 \\
P2 & 78.437 .081 & 7.253 \\
P3 & 9.348 .066 & 8.537 \\
P4 & 15.687 .416 & 1.451 \\
P5 & 28.064 .653 & 2.874 \\
P6 & 7.790 .055 & 7.114 \\
P7 & 70.161 .633 & 7.185 \\
P8 & 21.975 .326 & 20.929 \\
P9 & 38.950 .274 & 35.571 \\
P10 & 8.790 .130 & 8.372 \\
P11 & 6.232 .044 & 5.691 \\
\hline
\end{tabular}

\section{Unit Cost}

Perhitungan unit cost diperoleh dengan menjumlahkan seluruh biaya tidak langsung aktivitas primer dan biaya langsung setiap produk pelayanan poliklinik jantung. Berdasarkan hasil perhitungan unit cost dengan metode Activity Based Costing di poliklinik jantung RSU dr. H. Koesnadi Bondowoso, unit cost produk pelayanan electrocardiogram adalah Rp. 47.689, unit cost echocardiography adalah Rp. 113.212 dan produk pelayanan treadmill yaitu sebesar Rp. 221.547. Berikut adalah tabel yang menguraikan jumlah biaya langsung dan biaya tidak langsung hingga memperoleh unit cost untuk produk pelayanan polklinik jantung.

Tabel 6 Biaya Langsung, Biaya Tidak Langsung dan Unit Cost Produk Pelayanan Poliklinik Jantung

\begin{tabular}{lccc}
\hline \multicolumn{1}{c}{$\begin{array}{c}\text { Produk } \\
\text { Pelayanan }\end{array}$} & $\begin{array}{c}\text { Total } \\
\text { Biaya } \\
\text { Langsu } \\
\text { ng (Rp) }\end{array}$ & $\begin{array}{c}\text { Total } \\
\text { Biaya } \\
\text { Tidak } \\
\text { Langsu } \\
\text { ng (Rp) }\end{array}$ & $\begin{array}{c}\text { Unit } \\
\text { Cost } \\
\text { (BL+BT } \\
\text { L) (Rp) }\end{array}$ \\
\hline $\begin{array}{l}\text { Electrocardiog } \\
\text { ram }\end{array}$ & 25.995 & 21.694 & 47.689 \\
$\begin{array}{l}\text { Echocardiogra } \\
\text { phy }\end{array}$ & 72.276 & 40.935 & 113.212 \\
Treadmill & 161.702 & 59.845 & 221.547 \\
\hline
\end{tabular}

\section{Pembahasan}

Berdasarkan hasil wawancara dan studi dokumentasi, hasil identifikasi aktivitas penunjang poliklinik jantung terdiri dari pelayanan manajemen dan administrasi, pelayanan front office, pelayanan pengendali, pelayanan rekam medik, pelayanan SIM RS, pelayanan kasir, pelayanan farmasi, pelayanan laundry, pelayanan pemeliharaan sarana, pemeliharaan cleaning service, dan pelayanan keamanan. RSU dr. H. Koesnadi Bondowoso juga memiliki aktivitas penunjang lainnya yaitu instalasi sanitasi, instalasi CSSD dan instalasi gizi. Namun, instalasi sanitasi, instalasi CSSD dan instalasi gizi tidak dibebankan ke unit produksi poliklinik jantung karena tidak memberi pengaruh pada proses pelayanan poliklinik jantung RSU dr. H. Koesnadi Bondowoso.

Aktivitas penunjang yang dimaksud adalah aktivitas yang memberi dukungan terhadap proses pelayanan di poliklinik jantung dan aktivitas penunjang tidak dapat memberi keuntungan untuk rumah sakit karena tidak memiliki penghasilan atau tidak memilki output. Hal ini didukung dengan teori bahwa facility sustaining activity merupakan jenis aktivitas yang dikonsumsi oleh unit produksi atau jasa berdasarkan fasilitas atau sumber daya yang dimanfaatkan dalam proses penyediaan pelayanan (Mulyadi, 2007).

Berdasarkan hasil perhitungan yang telah dilakukan, aktivitas penunjang yang memiliki biaya tidak langsung terbesar adalah pelayanan manajemen dan administrasi dengan jumlah sebesar Rp. 3.527.531.568 dan biaya tidak langsung terkecil adalah pelayanan kasir yaitu sebesar Rp. 44.124.193. Hasil perhitungan penelitian ini memilki kesamaan dengan hasil perhitungan Rahmaniar dan Rochmah, (2017), yaitu biaya terbesar terletak pada pelayanan manajemen dan administrasi Komponen perhitungan biaya tidak langsung dalam penelitian ini meliputi biaya depresiasi, biaya operasional dan biaya pemeliharaan. Komponen biaya tidak 
langsung dalam penelitian ini sama dengan penelitian sebelumnya (Rahmaniar dan Rochmah, 2017).

Pembebanan biaya tidak langsung ke unit produksi dilakukan berdasarkan rate per cost driver dan cost driver. Hasil perkalian rate per cost driver dengan cost driver poliklinik jantung diperoleh bahwa pembebanan biaya terbesar terletak pada pelayanan front office yaitu sebesar $\mathrm{Rp}$. 94.510.768 dan biaya terkecil adalah pelayanan laundry dengan jumlah $\mathrm{Rp}$. 424.828. Besar kecilnya cost driver akan mempengaruhi besar kecilnya pembebanan biaya tidak langsung dari aktivitas penunjang ke unit produksi. Hal ini sesuai dengan teori yang telah dikemukakan bahwa pembebanan biaya tidak langsung ke unit produksi dipengaruhi oleh rate per cost driver dan perhitungan rate per cost driver dipengaruhi oleh total cost driver (Mulyadi, 2007). Hal ini juga dapat terlihat pada penelitian Oashttamadea, et al (2019), cost driver memberikan pengaruh terhadap pembebanan biaya ke unit produksi.

Komponen biaya langsung terdiri dari biaya bahan medis, biaya tenaga medis dan paramedis dan biaya alat medis. Hal ini sesuai dengan komponen biaya yang ada dalam teori Mulyadi (2007:253), bahwa biaya langsung terdiri dari biaya bahan, biaya alat, dan biaya personel atau yang disebut dengan tenaga kerja medis dan paramedis. Biaya langsung pasti berlaku untuk setiap rumah sakit, karena biaya ini terjadi akibat dari adanya aktivitas yang menggunakan sumber daya yang diberikan secara langsung kepada pasien. Hal ini ditunjang oleh teori (Mulyadi, 2007) yang menyatakan bahwa biaya langsung merupakan biaya yang secara langsung dibebankan ke produk pelayanan. Berdasarkan perhitungan diperoleh bahwa total biaya tidak langsung adalah sebesar Rp. 65.337.348. Biaya tidak langsung tersebut berasal dari unit produksi yang terdiri beberapa komponen biaya, yaitu biaya depresiasi, biaya operasional dan biaya pemeliharaan. Komponen biaya pada penelitian ini memiliki kesamaan dengan penelitian sebelumnya (Wahyuni, et al, 2017).

Pembebanan aktivitas sekunder ke aktivitas primer merupakan langkah yang mempunyai fungsi untuk mengalokasikan jenis aktivitas sekunder ke aktivitas primer. Hal ini terjadi karena aktivitas sekunder tidak dapat dibebankan secara langsung ke produk pelayanan. Hal tersebut sesuai dengan teori yang menyatakan bahwa aktivitas sekunder adalah aktivitas pada unit produksi yang dapat menambah biaya dari produk, namun tidak dapat meningkatkan biaya produk secara langsung sehingga jenis aktivitas sekunder harus dibebankan ke aktivitas primer (Mulyadi, 2007). Metode Activity Based Costing dapat memberi informasi biaya yang dibebankan ke produk pelayanan adalah biaya untuk masingmasing aktivitas (Soekardan, 2016).

Pembebanan biaya aktivitas sekunder ke aktivitas primer membutuhkan biaya sehingga mempengaruhi total biaya tidak langsung per aktivitas primer. Hal ini didukung oleh teori yang menyebutkan bahwa menghitung biaya tidak langsung pada aktivitas primer dapat dipengaruhi oleh alokasi biaya yang berbasis aktivitas (Mulyadi, 2007). Berdasarkan teori tersebut dapat disimpulkan bahwa semakin besar jumlah aktivitas sekunder maka akan mempengaruhi total biaya tidak langsung per aktivitas primer. Selain itu, jika jumlah pasien yang digunakan untuk pembagi total biaya tidak langsung per aktivitas primer semakin besar maka akan membuat nilai rate per aktivitas primer semakin kecil. Rate per aktivitas primer setiap produk pelayanan yang dijumlahkan berdasarkan kategori unit activity digunakan sebagai biaya tidak langsung dalam perhitungan biaya satuan dengan metode Activity Based Costing.

Perhitungan unit cost dengan metode Activity Based Costing merupakan penjumlahan biaya tidak langsung dengan biaya langsung setiap produk. Berdasarkan perhitungan yang dilakukan diperoleh unit cost untuk produk pelayanan electrocardiogram, echocardiography dan treadmill berturut-turut adalah sebesar Rp. 
47.689, Rp. 113.212 dan Rp. 221.547. Berdasarkan hasil perhitungan dapat diketahui bahwa unit cost lebih rendah dari tarif yang ditetapkan oleh RSU dr. H. Koesnadi Bondowoso. Jika dibandingkan dengan tarif INA-CBG's, unit cost produk pelayanan electrocardiogram dan echocardiography lebih rendah dari tarif INA-CBG's. Berbeda halnya dengan unit cost produk pelayanan treadmill yang lebih tinggi dari tarif INA-CBG's.

\section{Simpulan dan Saran}

Kesimpulan dalam penelitian ini adalah aktivitas penunjang poliklinik jantung terdiri dari pelayanan manajemen dan administrasi, pelayanan front office, pelayanan pengendali, pelayanan rekam medik, pelayanan SIM RS, pelayanan kasir, pelayanan farmasi, pelayanan laundry, pelayanan pemeliharaan sarana, pemeliharaan cleaning service, dan pelayanan keamanan. Biaya tidak langsung pada aktivitas penunjang (facility activity) yang terbesar adalah pelayanan manajemen dan administrasi dengan jumlah sebesar Rp. 3.527.531.568. Biaya pembebanan terbesar adalah pelayanan front office yaitu sebesar Rp. 94.510.768. Waktu pelayanan primer terbanyak adalah produk pelayanan treadmill yaitu selama 42 menit. Total biaya langsung terbesar adalah biaya produk pelayanan treadmill yaitu sebesar Rp. 161.702 dan total biaya tidak langsung poliklinik jantung adalah sebesar Rp. 65.337.348. Rate per aktivitas primer terbesar adalah aktivitas primer 9 yang dimiliki oleh produk pelayanan treadmill yaitu sebesar Rp. 35.571. Unit cost produk pelayanan electrocardiogram adalah $\mathrm{Rp}$. 47.689, unit cost echocardiography adalah Rp. 113.212 dan produk pelayanan treadmill yaitu sebesar Rp. 221.547. Berdasarkan hasil perhitungan dapat diketahui bahwa unit cost lebih rendah dari tarif yang ditetapkan.

Berdasarkan kesimpulan, saran yang dapat diberikan adalah pihak manajemen RSU dr. H. Koesnadi Bondowoso perlu melakukan peninjauan ulang terhadap penetapan tarif karena aktivitas, kebutuhan dan biaya setiap tahun berbeda bahkan cenderung meningkat. Evaluasi tarif dapat dimulai dengan melakukan perhitungan biaya satuan dengan metode Activity Based Costing karena dapat menghasilkan perhitungan harga pokok atau tarif yang lebih akurat. Hal tersebut dikarenakan perhitungan biaya satuan dengan metode Activity Based Costing dilakukan berdasarkan cost driver yang dapat mencerminkan aktivitas.

\section{Daftar Pustaka}

Agastya A. 2009. Unit Cost dan Tarif Rumah Sakit (Metode Analisis dan Cara Perhitungan) Limited Edition: Yogyakarta Gajah Mada.

Hilfi, Lukman, et al. 2015. Perbedaan Perhitungan Unit Cost dengan Metode Activity Based Costing (ABC) dan Metode Double Distribution (DD) untuk Pasien TB Paru Kategori 2 di Instalasi Rawat Jalan dan Rawat Inap Rumah Sakit Paru. JSK, 2[1]:64

Javid, Mahdi, et al. 2016. Applicationof the Activity Based Costing Method for Unit Cost Calculation in a Hospital. Global Journal of Health Science. 8(1).165172.

Mulyadi. 2007. Activity-Based Cost System: Sistem Informasi Biaya untuk Pemberdayaan Karyawan, Pengurangan Biaya, dan Penentuan Secara Akurat Kos Produk dan Jasa. Edisi Keenam - Catatan ke-2. Yogyakarta: UPP AMP YKPN.

Oashttamadea, Ressa, et al, 2019. Analisis Unit Cost Pelayanan Unit Laboratorium Rumah Sakit Naili DBS Tahun 2017 dengan Metode Activity Based Costing (ABC). Jurnal Kesehatan Andalas. 2(8). 8-14.

Proqua Consulting. 2016. Unit Cost Berbasis Clinical Pathway dan Cost Containment dengan Metoda Activity Based Costing. Surakarta: Hospital Management Training \& Consulting.

Rajabi, A dan A Dabiri, 2012. Applying Activity Based Costing (ABC) Method to Calculate Cost Price in Hospital and 
Remedy Services. Iranian Journal of Public Health. 41(4).100-107.

Rahmaniar, Dinda dan Thinni Nurul Rochmah. 2017. Analisis Biaya Satuan Metode Activity Based Costing (ABC) dalam Evaluasi Tarif Pelayanan di Klinik Spesialis Bedah Saraf Rumah Sakit "X" Surabaya. Jurnal

Manajemen Kesehatan. 1(3). 76-87.

Republik Indonesia, 2005. Peraturan

Pemerintah Republik Indonesia Nomor 23 Tahun 2005 tentang Pengelolaan Keuangan Badan Layanan Umum. Jakarta.

Republik Indonesia, 2009. Undang-Undang Nomor 44 Tahun 2009 Tentang Rumah Sakit. Jakarta.

Soekardan, Dadan. 2016. An Analysis of Activity Based Costing: Between Benefit and Cost for its Implementation. International Journal of Scientific \& Technology Research. 6(5). 334-339.

Wahyuni, Nurlely Tri, et al. 2017. Analisis Unit Cost Pelayanan Rawat Inap Postpartum di Rumah Sakit Umum Dewi Sartika dengan Menggunakan Metode Activity Based Costing (ABC) System. Jurnal Ilmiah Mahasiswa Kesehatan Masyarakat. 5(2). 